\title{
Czeczenia w polskiej prasie w latach 90. XX wieku Na przykładzie analizy wybranych opiniotwórczych tygodników
}

\section{Wstęp i metodologia}

Współcześnie Czeczenia, będąca jedną z republik wchodzących w skład terytorium Federacji Rosyjskiej, nie przypomina targanej konfliktami republiki z lat 90 . XX w. O ile ponad 20 lat temu głównym tematem rozważań publicystów i ekspertów była kwestia rozwiązania trwającego konfliktu, w ostatnich latach temat Czeczenii pojawia się zazwyczaj w kontekście postępującej islamizacji tego obszaru Federacji Rosyjskiej. Jak zaznaczają badacze, m.in. Elena Arljapowa, obecnie to właśnie islam wykorzystywany jest jako źródło legitymizacji i konsolidacji władzy w republice ${ }^{1}$. Bez wątpienia symbolem tego procesu jest głowa Republiki Czeczeńskiej Ramzan Kadyrow², utrzymujący bardzo bliskie relacje z centralnymi organami władzy, na czele z Prezydentem Rosji Władimirem Putinem i mogący liczyć na wsparcie finansowe z rosyjskiej stolicy. Dla Czeczenów spokój w republice jest jednak ważniejszy niż dyktatorskie zapędy przywódcy republiki czy otwarte eksponowanie lojalności w stosunku do władz centralnych. Przykłady można wyliczać: jest to chociażby nazwanie jednej z głównych ulic w Groznym imieniem Władimira Putina czy wypowiedzi Kadyrowa, w których wyraża on opinię, iż Putin powinien sprawować swój urząd dożywotnio ${ }^{3}$, a samego prezydenta określa jako człowieka, który „przyczynił się do powstania kraju z kolan”4. Chociaż we współczesnej polskiej prasie temat Czeczenii nie wykracza poza wskazane powyżej kwestie, warto spojrzeć na jej wizerunek obecny w prasie w latach 90. XX w.

${ }^{1}$ Е. Арляпова, Ислам как источник легитимации и консолидации власти в Чеченской Республике, „Политическая Наука” 2013, nr 2, s. 177-192.

${ }^{2}$ Ramzan Kadyrow (ur. 1976 r.) - obecnie czołowy polityk czeczeński, jednocześnie pełniący urząd szefa republiki. Syn zmarłego w zamachu w 2004 r. Achmata Kadyrowa. W 2007 r. został prezydentem Republiki Czeczeńskiej, zastępując na tym stanowisku Ału Akchanowa. Szerzej zob. A. Малашенко, Рамзан Кадьров: российский политик кавказской национальности, Москва 2009.

${ }^{3}$ W. Górecki, Dokąd zmierza Kaukaz Pótnocny, „Nowa Europa Wschodnia” 2011, nr 6(XX), s. $77-84$.

${ }^{4}$ Кадыров: Путин стал знаковой фигурой в истории Чечни, https://kavkaz.mk.ru/poli tics/2019/08/17/kadyrov-putin-stal-znakovoy-figuroy-v-istorii-chechni.html, dostęp 12.09.2019. 
Celem niniejszego artykułu jest przedstawienie problematyki czeczeńskiej na łamach polskiej prasy w kontekście pierwszej wojny czeczeńskiej. W artykule analizie poddane zostały dwa tygodniki: „Polityka” oraz „Wprost”. Główną przesłanką doboru tygodników jest ich rozróżnienie ideologiczne. „Polityka” jest ogólnopolskim tygodnikiem zajmującym się tematami społeczno-politycznymi. Zakres tematów obecnych na łamach polityki to przede wszystkim bieżące wydarzenia polityczne, gospodarcze, naukowe czy kulturalne z Polski, Europy oraz świata. Tygodnik publikuje felietony, reportaże, bieżące komentarze oraz pogłębione analizy ${ }^{5}$. Tygodnik prezentuje liberalno-lewicowy profil polityczny. Historia „Polityki” sięga roku 1957, a jednym z jej założycieli i późniejszym redaktorem naczelnym był Mieczysław Rakowski ${ }^{6}$. „Wprost” charakteryzuje się natomiast zdecydowanie liberalno-konserwatywnym profilem. Zakres tematyczny oraz prezentowanych form publicystyczny zbliżony jest do jednak do tygodnika „Polityka”. Analizie ilościowej oraz jakościowej poddano wszystkie wydania wspomnianych wyżej tygodników z lat 1995-1996 oraz wydania z końca 1994 r., a więc okres obejmujący czas trwania pierwszej wojny czeczeńskiej .

\section{Rosja i Czeczenia w polskich tygodnikach opinii - ujęcie ilościowe}

Przed wybuchem pierwszej wojny czeczeńskiej liczba artykułów, reportaży czy komentarzy poświęconych Czeczenii, zarówno w tygodniku „Polityka”, jak i „Wprost” nie przekraczała pięciu. Wraz z rozpoczęciem działań wojennych kwestia sytuacji na Kaukazie znalazła się w centrum zainteresowania także polskich tygodników opinii, a liczba samych artykułów znacząco wzrosła. Podkreślić jednak należy, ze jedynie w 1995 r. ukazało się najwięcej różnorodnych form publicystycznych poświęconych samej Czeczenii oraz działaniom związanym z pierwszą wojną czeczeńską. W 1995 r. ukazało się 61 artykułów poświęconych Rosji, z czego 20 dotyczyła samej Republiki Czeczeńskiej lub wojny czeczeńskiej. Artykuły te stanowiły zatem $33 \%$ wszystkich poświęconych Rosji jakie ukazały się na łamach tygodnika „Polityka”. W tym samym czasie w tygodniku „Wprost” ukazało się 48 artykułów zaadresowanych Rosji, wśród nich 11 dotyczyło Czeczenii, co stanowi 23\% wszystkich artykułów poświęconych Rosji. W roku 1996 zainteresowanie Czeczenią i wojną znacznie zmalało wśród polskich autorów publikujących na łamach tygodników. W „Polityce” ukazały się

${ }^{5}$ Prasa w Polsce, https://web.archive.org/web/20130312090627/http://www.poland.gov.pl/Prasa,w,Polsce,6676.html, dostęp 12.09.2019.

${ }^{6}$ W. Władyka, Z. Rykowski, Syndrom „Polityki”, „Kwartalnik Historii Prasy Polskiej” 1988, nr 27/1, s. 85-100.

${ }^{7}$ Prasa $w$ Polsce...

${ }^{8}$ Pierwsza wojna czeczeńska - konflikt zbrojny pomiędzy czeczeńskimi siłami separatystycznymi i rosyjskimi wojskami federalnymi trwający od 11 grudnia 1994 r. do 31 sierpnia 1996 r. 
73 artykuły poświęcone Rosji, z czego zaledwie 11 odnosiły się do Czeczenii i wojny czeczeńskiej (15\% wszystkich artykułów na temat Rosji). Dość podobnie przedstawia się sytuacja tygodnika „Wprost”, bo w 1996 r. opublikowano tu 39 artykułów na temat Rosji, z czego sześć dotyczyło Czeczenii.

\section{Czeczenia w tygodnikach - najpopularniejsze tematy}

Pierwsza wojna czeczeńska postrzegana jest jako jeden z najtragiczniejszych epizodów w najnowszej historii Rosji i świata. Jak podkreślają badacze zajmujący się historią Rosji, w tym Nicholas Riasanovsky,

obie strony konfliktu wykazały się równie wielką ambicją i nieustępliwością, a stolica Czeczenii, Grozny, a także reszta terytorium republiki zamieniły się w pole walki, porównywane często z Wietnamem czy - bardziej po sąsiedzku - z Afganistanem. Podczas nieuniknionych w czasie wojny przypadków śmierci i zniszczeń odnotowano przykłady wyjątkowego, zamierzonego okrucieństwa, takie jak pogrom ludności cywilnej we wsi Samaszki, dokonany pomiędzy 6 a 8 kwietnia 1995 r. przez siły specjalne Ministerstwa Spraw Wewnętrznych'.

Konflikt, który trwał od 11 grudnia 1994 r. do 31 sierpnia 1996 r. pochłonął ponad 40 tysięcy ofiar ${ }^{10}$. Warto jednak podkreślić, że już w połowie XIX stulecia. muzułmański naród czeczeński walczył wraz ze swoim przywódcą Szamilem o zachowanie niezależności od Rosji, a po 1917 r. stawiał także opór mocarstwu sowieckiemu ${ }^{11}$. Działania te obarczone były tragicznymi konsekwencjami, bo Stalin zdecydował się deportować po drugiej wojnie światowej Czeczenów do Azji Środkowej, a ich powrót do ojczyzny możliwy był dopiero po śmierci dyktatora ${ }^{12}$. Po upadku ZSRS, kiedy to republiki związkowe ogłosiły niezawisłość na przywódcę Czeczenii wybrano Dżohara Dudajewa, który w 1991 r. został prezydentem Czeczenii oraz ogłosił jej niepodległość wraz z powstaniem nowego państwa, jakim była Czeczeńska Republika Iczkeriii ${ }^{13}$. Niestabilna sytuacja w państwie rosyjskim w owym czasie przyczyniła się do rozwoju przestępczości na tym terenie, a nieudolne próby obalenia nowej władzy - do podjęcia interwencji zbrojnej przez Kreml, która miała miejsce 11 grudnia 1994 r.

Artykuły poświęcone zarówno Rosji ${ }^{14} \mathrm{w}$ ogóle, jak i samej Czeczenii, które ukazały się na łamach „Polityki” i „Wprost”, można podzielić na kilka głównych

\footnotetext{
${ }^{9}$ N. Riasanovsky, M. Steinberg, Historia Rosji, Kraków 2009, s. 664-665.

${ }^{10}$ Ibidem.

${ }^{11}$ Ibidem.

${ }^{12}$ Ibidem.

${ }^{13}$ Ibidem.

${ }^{14}$ Najpopularniejsze tematy artykułów poświęcone Rosji obejmują takie zagadnienia, jak: pozycja Federacji Rosyjskiej na arenie międzynarodowej; sytuacja wewnętrzna w Rosji (m.in. wybory prezydenckie i postać Borysa Jelcyna, sytuacja rosyjskiej armii, rosyjska mafia, problemy
} 
grup tematycznych. Są to: wybuch pierwszej wojny czeczeńskiej i operacja militarna w Groznym, działania wojenne (w tym działania w Budionnowsku), konsekwencje wojny (w wymiarze społecznym i politycznym), czeczeńscy przywódcy. Warto podkreślić, że sam konflikt w Czeczenii spowodował wzmożone zainteresowanie polskiej prasy nie tylko samą republiką, lecz także Kaukazem oraz zmianami politycznymi w Rosji. Niespodziewanie temat pierwszej wojny czeczeńskiej powrócił do polskiej debaty publicznej dopiero po roku 2015 wraz z ogólnoeuropejską i ogólnopolską dyskusją na temat kryzysu emigracyjnego w Europie. Jak zaznacza Komisja Europejska, „w latach 2015-2016 Unia Europejska doświadczyła bezprecedensowego napływu uchodźców i migrantów. Do Unii Europejskiej przybyło ponad milion osób - większość z nich uciekała przed wojną i terrorem w Syrii i innych krajach"15. Wraz z dyskusją na temat przyjmowania uchodźców do krajów Unii Europejskiej i niechętnej postawie wobec tych działań polskiego $\mathrm{rządu}^{16} \mathrm{~W}$ prasie i mediach elektronicznych zaczęły pojawiać się informacje nawiązujące do wojny czeczeńskiej i postawy Polski w owym czasie, która przyjmowała uchodźców z Czeczenii ${ }^{17}$.

\section{Wybuch pierwszej wojny czeczeńskiej}

Pierwszą grupą tematyczną artykułów poświęconych sytuacji Czeczenii w latach 90. XX w., które ukazały się w tygodnikach „Polityka” oraz „Wprost” są te poświęcone wydarzeniom związanym z samym wybuchem wojny. W tygodniku „Polityka”, w wydaniu z dnia 31 grudnia 1994 r., znalazł się artykuł Kolejna wojna w Europie autorstwa profesora Krzysztofa Skubiszewskiego oraz profesora Zbigniewa Brzezińskiego. Chociaż sam tytuł oraz późniejsze opinie wspomnianych ekspertów wybrzmiewają raczej w neutralnym tonie, to wstęp do artykułu przygotowany przez redakcję nakreśla już na samym początku czytelnikom, kto jest po dobrej, a kto po złej stronie w tym konflikcie. Możemy zatem przeczytać, iż „Grozny jest celem operacji wojsk rosyjskich. W Święta Bożego Narodzenia (identyczny termin wybrano w 1979 r. na wysadzenie radzieckiego desantu w Kabulu) świat zachodni siedzi przy choince, śpiewa kolędy, a prawosławni załatwiają tymczasem z muzułmanami sprawy wewnętrzne"18. Rozwinięcie artykułu na kolejnych stronach przynosi

społeczne); relacje polsko-rosyjskie (np. kształt relacji polsko-rosyjskich w kontekście przystąpienia Polski do NATO, wzajemne postrzeganie Polaków i Rosjan).

${ }^{15}$ Kryzys migracyjny, http://publications.europa.eu/webpub/com/factsheets/migration-crisis/ $\mathrm{pl} /$, dostęp 12.09.2019.

${ }^{16}$ Błaszczak: nie przyjmiemy ani jednego uchodźcy. Polityka UE samobójcza, https://www.polsatnews.pl/wiadomosc/2017-05-16/blaszczak-nie-przyjmiemy-ani-jednego-uchodzcy-polityka-ue-samobojcza/, dostęp 14.09.2019.

${ }^{17} \mathrm{~K}$. Zuchowicz, Polska przyjęła już ponad 80 tysięcy Czeczenów $i$ wciąż przyjmuje następnych. Czy komuś to przeszkadza?, https://natemat.pl/155107,polska-przyjela-juz-blisko-90-tysiecy-uchodzcow-z-czeczenii-dzis-zostala-ich-tylko-garstka-bo-nie-chcieli-u-nas-zostac, dostęp 12.09.2019.

${ }^{18}$ K. Skubiszewski, Z. Brzeziński, Kolejna wojna w Europie, „Polityka” 1994, nr 53(1965), s. 1. 
jednak bardziej szczegółowy, rzeczowy i chłodny komentarz. Kwestia na którą zwraca uwagę Skubiszewski, to głównie wieloaspektowy wymiar konfliktu na Kaukazie. Przekonuje on, że wojnę czeczeńską rozpatrywać należy w aspekcie politycznym, prawnym, moralnym czy gospodarczym, a „reagując na ten konflikt i na konflikty podobne, nie należy tych aspektów od siebie oddzielać - mimo że każdy z nich jest do pewnego stopnia samodzielny"19.

Badacz zaznacza jednak, że prawo międzynarodowe chroni integralność terytorialną państwa, a sama Czeczenia pozostaje $\mathrm{w}$ granicach Federacji Rosyjskiej i nie została uznana przez społeczność międzynarodową za państwo ${ }^{20}$. Z kolei w drugiej części artykułu Zbigniew Brzeziński podkreśla, że

rezygnacja z krytyki rządu rosyjskiego na gruncie moralnym, a tylko wyrażanie nadziei, że ład zostanie przywrócony, jest postawą na poziomie Żyrynowskiego, a (...) formalne stanowisko [Polski - A.S.] powinno być jednocześnie wyrazem poparcia moralnego dla sił demokratycznych w Rosji, które sprzeciwiają się użyciu siły. Winno być wyrazem sympatii dla moralnie usprawiedliwionych aspiracji Czeczenów oraz podziwu dla ich odwagi w oporze przeciwko imperialistycznemu jarzmu ${ }^{21}$.

Kwestie odpowiedzialności moralnej za konflikt wybrzmiewają zresztą na łamach „Polityki” dość wyraźnie - doskonałym tego przykładem jest artykuł z 14 stycznia 1995 r. autorstwa Mariny Sylwańskiej-Pawłowej Uczta w czasie dżumy ${ }^{22}$. W artykule tym autorka zastanawia się jaką rolę $\mathrm{w}$ tym konflikcie odgrywają wolne media w Rosji i czy ich istnienie ma wpływ na postrzeganie przez społeczeństwo rosyjskie i nie tylko tego konfliktu. Znamienne wydają się słowa autorki, która opisując sytuację w Rosji, pisze, że „zderzenie władzy działającej poza kontrolą polityczną z wolnością środków masowej informacji jest dla Rosji zjawiskiem całkowicie nowym"23. Rozważania autorki artykułu konstatują dość wyraziste słowa prezentujące niejako w pigułce stan rosyjskiej demokracji i świadomości mieszkańców Rosji:

Przegniły, skorumpowany reżim w połączeniu z wolnością słowa - to jednak straszliwa, zgubna mieszanka, zagrażająca podstawom tego, co na Zachodzie nazywa się społeczeństwem obywatelskim. Z sondaży opinii wynika, że trzy czwarte społeczeństwa nie ufa prezydentowi i nie aprobuje użycia siły w Czeczenii. Jednakże z otwartymi protestami w tej sprawie występowała w ostatnich tygodniach garstka wciąż tych samych ludzi - pół setki podstarzałych moskiewskich intelektualistów i dysydentów ${ }^{24}$.

\footnotetext{
${ }^{19}$ Ibidem.

${ }^{20}$ Ibidem

${ }^{21}$ Ibidem

${ }^{22}$ M. Sylwańska-Pawłowa, Uczta w czasie dżumy, „Polityka” 1995, nr 2(1967), s. 10.

${ }^{23}$ Ibidem.

${ }^{24}$ Ibidem.
} 
W tygodniku „Wprost” w tym samym czasie ukazał się m.in. artykuł Dawid $i$ goliat, który stanowi wywiad z Hamadem Kurbanowem, stałym przedstawicielem Republiki Czeczeńskiej w Moskwie ${ }^{25}$. W rozmowie z Kurbanowem czytelnicy poznają zupełnie inny aspekt trwającego konfliktu w Czeczenii. Przedstawiony został zakulisowy wymiar rosyjsko-czeczeńskiej dyplomacji, co dla samej oceny trwającego konfliktu jest również niezwykle ważne. Według Kurbanowa to właśnie rosyjskie władze odpowiedzialne są nie tylko za faktyczne działania zbrojne $\mathrm{w}$ republice, ale także odpowiedzialne są za zaniechania dyplomatyczne w kwestii statusu republiki, gdyż, jak zaznacza rozmówca, przez blisko trzy lata nie reagowały na oficjalne zaproszenia i propozycje władz Czeczenii. Jak podkreśla Kurbanow:

Dotychczas narody i republiki wchodzące w skład Rosji nie były zainteresowane odłączaniem się, dopiero dzisiejsza polityka Kremla wobec Czeczenii uświadomiła im, z jaką Rosją mają do czynienia. Małym narodom pozostała już tylko secesja. Wraz z wydarzeniami w Czeczenii rozpoczął się proces rozpadu wielonarodowej Rosji ${ }^{26}$.

Wywiad kończy dosyć pesymistyczna konstatacja:

Bóg nie dał nam innej drogi. Jest to historyczna wojna narodu czeczeńskiego z Rosją - prowadzimy ją od ponad trzystu lat i nie możemy z niej teraz zrezygnować; będzie trwała jeszcze długo i będą ją kontynuowały następne pokolenia ${ }^{27}$.

\section{Działania wojenne - Budionnowsk}

Kolejną grupę artykułów stanowią te poświęcone działaniom wojennym. Spośród nich największym echem w prasie rosyjskiej, ale również w polskiej prasie odbiły się wydarzenia związane $\mathrm{z}$ atakiem czeczeńskich separatystów na szpital w Budionnowsku (Kraj Stawropolski) 14-19 czerwca 1995 r. $^{28}$ Zarówno w „Polityce”, jak i w tygodniku „Wprost” znajdują się artykuły poświęcone temu zagadnieniu. W wydaniu „Polityki” z 1 lipca 1995 r. ukazał się artykuł Witolda Laskowskiego $Z$ wdzięczności do oprawcy ${ }^{29}$, będący swoistą relacją działań związanych ze szturmem rosyjskich oddziałów specjalnych na szpital oraz negocjacji z terrorystami pod wodzą Szamila Basajewa. W artykule autor przedstawia życie i historie zwykłych ludzi, jednocześnie mieszkańców miasta, których los nieoczekiwanie wplątał w jeden z najtragiczniejszych

\footnotetext{
${ }^{25}$ H. Kurbanow, Dawid i goliat, „Wprost” 1995, nr 1, s. 20.

${ }^{26}$ Ibidem.

${ }^{27}$ Ibidem.

${ }^{28}$ М.Ю. Колосницына, Террористы и заложники: история вопроса, „Прикладная юридическая психология” 2008, nr 2, s. 35-55.

${ }^{29}$ W. Laskowski, Z wdzięczności do oprawcy, „Polityka” 1995, nr 26(1991), s. 13.
} 
konfliktów współczesnych czasów. Jak relacjonuje jedna z bohaterek artykułu, niejaka Natalia:

Każdy tutaj ma wśród zakładników kogoś bliskiego. Życie u nas jest surowe, przywykliśmy pomagać i wierzyć ludziom, ale okazało się, że nie wszyscy są ludźmi (...) Prowadzili ich jak bydło na rzeź, w pewnym momencie uciekłam ze strachu. Gdybym wtedy wiedziała, że tam jest moja córka... poszłabym do końca... ${ }^{30}$

Artykuł i zawarte w nim historie zwykłych ludzi ukazują bez wątpienia okrucieństwo działań wojennych, ale głównie okrucieństwo samych terrorystów-Czeczenów. Relacje mieszkańców Budionnowska jednoznacznie wskazują na Czeczenów jako ludzi, którzy atrybutów człowieczeństwa nie posiadają. Jak mówi jeden z mieszkańców miasta: „To po prostu zwierzęta. Ja ich znam, bo z nimi wyrosłem. Daj im broń, to będą strzelać do ostatniego naboju"31.

W tygodniku „Wprost” 2 lipca 1995 r. ukazał się natomiast artykuł Stanisława Janeckiego Pokój budionnowski? ${ }^{32}$ Autor dokonuje dosyć skrupulatnej i niezwykle precyzyjnej analizy postawy ówczesnych organów władzy Federacji Rosyjskiej w odniesieniu do czeczeńskich separatystów po tym, jak ci ostatni przeprowadzili krwawy atak na szpital w stutysięcznym mieście, na rosyjskiej prowincji. Jak zaznacza autor, „Basajew zmusił Rosjan do rokowań, mimo że najpierw strzelał do kobiet i dzieci oraz powiesił ciężarną kobietę na oczach jej kilkunastoletniej córki”33. Zdaniem autora, rządzący Rosją nie liczą się z czymkolwiek oprócz siły, a dopiero tak straszliwy akt terroru skłonił Rosjan do przerwania walk w Czeczenii. Po raz kolejny również na łamach „Wprost” pojawia się nawiązanie do tzw. syndromu sztokholmskiego, a zawarte w nim relacje świadków zdają się przedstawiać także ludzki wymiar działalności terrorystów. Przytoczone zostają słowa 30-letniej pielęgniarki:

Basajew powiedział nam, że w bombardowaniu zginęła prawie cała jego rodzina, czeczeńskie miasta i wioski zamieniono w płonące zgliszcza. Oni czują się jak wilki w czasie obławy, a kąsają tylko wtedy, gdy zadaje się im śmiertelne rany ${ }^{34}$.

Przytoczone zostają również słowa rosyjskich mediów, które w swoich relacjach sytuację w Budionnowsku porównywały do wydarzeń w Palestynie i Ulsterze. Autor stwierdza, że wymuszony terrorem Basajewa budionnowski pokój „może się więc okazać jedynym wyjściem dla obu stron” ${ }^{35}$.

\footnotetext{
${ }^{30}$ Ibidem.

${ }^{31}$ Ibidem

${ }^{32}$ S. Janecki, Pokój budionnowski, „Wprost” 1995, nr 27, s. 25-26.

${ }^{33}$ Ibidem.

${ }^{34}$ Ibidem

${ }^{35}$ Ibidem.
} 


\section{Czeczeńscy przywódcy}

Osobną grupę artykułów, godną uwagi stanowią te odnoszące się do opisu postaci związanych z czeczeńskimi przywódcami. Niezaprzeczalnie najważniejszą postacią w tym gronie jest Dżohar Dudajew. Urodził się w 1944 r. w Czeczeńsko-Inguskiej Autonomicznej Socjalistycznej Republice Radzieckiej. Był trzynastym, najmłodszym dzieckiem w rodzinie. Kiedy w lutym 1944 r. rozpoczęły się masowe represje, został deportowany wraz z rodziną do Azji Centralnej, a do Czeczenii powrócił dopiero w 1957 r. ${ }^{36}$ Od 1962 r. rozpoczą służbę w armii sowieckiej. Do 1991 r. praktycznie nie angażował się w działalność polityczną, chociaż w 1990 r. jako szef garnizonu w estońskim mieście Tartu odmówił wykonania rozkazu zablokowania telewizji i parlamentu. Właściwą działalność polityczną rozpoczął dopiero w 1991 r., kiedy to został wybrany na prezydenta Czeczeńskiej Republiki Iczkerii. Na początku marca 1992 r. parlament Czeczenii przyjął konstytucję, która określała podstawy działania nowego świeckiego państwa. W tym samym roku Dudajew odbył nawet podróż na Bliski Wschód, między innymi do Arabii Saudyjskiej i Kuwejtu, jednakże państwa te nie zgodziły się uznać niepodległości Czeczenii na arenie międzynarodowej ${ }^{37}$. Po wkroczeniu sił specjalnych do Czeczenii rozpoczęły się próby zgładzenia Dudajewa - jak relacjonowały rosyjskie media kilkukrotnie próbowano infiltrować jego najbliższe otoczenie oraz zaminować samochód, w którym się poruszał, jednak bezskutecznie. Ostatecznie siłom rosyjskim udało się zorganizować skuteczny zamach na czeczeńskiego przywódcę dopiero 22 kwietnia 1996 r. $^{38}$

Warto zwrócić uwagę na artykuł autorstwa Ewy Robaczyńskiej-Ewart Wywiad z cieniem, który ukazał się na łamach tygodnika „Polityka” 23 grudnia $1995 \mathrm{r}^{39}$ Jest to jeden z najlepszych i najciekawszych materiałów, który ukazał się w polskich mediach na temat Dżohara Dudajewa, a słowa, które padają z ust Dudajewa w czasie bardzo krótkiego wywiadu okazują się znamienne i prorocze dla wydarzeń, które będą mieć miejsce w Rosji w późniejszych latach. Autorka artykułu na samym początku opisuje dość skomplikowany proces spotkania się z prezydentem republiki - wszakże jest to człowiek będący na celowniku rosyjskich służb. Po wielotygodniowych próbach, spotkaniach z czeczeńskimi urzędnikami, przedstawicielami Dudajewa, służbą ochrony, wreszcie ekipie dziennikarskiej udaje się wyruszyć w podróż w góry Kaukazu, aby spotkać się z nieuchwytnym człowiekiem cieniem. Już na wstępie rozmowy Dudajew poddaje ocenie naród rosyjski: „Rosjanie to chory naród, naród

\footnotetext{
${ }^{36}$ Дудаев Джохар Мусаевич, https://www.kavkaz-uzel.eu/articles/117231/, dostęp 12.09.2019.

${ }^{37}$ Ibidem.

${ }^{38}$ Ibidem.

${ }^{39}$ E. Robaczyńska-Ewart, Wywiad z cieniem, „Polityka” 1995, nr 51(2016), s. 40-41.
} 
schizofreników cierpiących na manię wielkości, dominowania nad światem"40. Jak zaznacza dalej: „Tylko śmierć zmusi mnie do poddania. Mam zamiar zbudować silne państwo, zdolne oprzeć się wszelkiemu złu i przemocy" ${ }^{41}$. Jednak prezydent przyznaje też, że w obecnej sytuacji wojna jest mu po prostu potrzebna: „Cóż bym uczynił z 300 tysiącami bezrobotnych, pozbawionych dachu nad głową i umiejących jedynie wojować? Potrzebny jest mi wróg, przeciwko

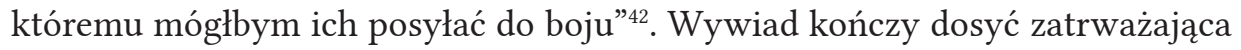
konstatacja i wizja przyszłości: „Moim zamiarem jest (...) wniknięcie w głąb kraju i zniszczenie go od wewnątrz. Pamiętacie Budionnowsk? To była tylko przygrywka, wstęp. Trzeba będzie to powtórzyć" ${ }^{43}$. Słowa Dudajewa okazały się prorocze, wystarczy przypomnieć zamachy we Władykaukazie z 1999 r., atak terrorystyczny na moskiewski teatr na Dubrowce z 2002 r. czy terrorystyczny na szkołę w Biesłanie w $2004 \mathrm{r}$.

Po śmierci Dudajewa w polskiej prasie pojawiły się również artykuły dotyczące tej postaci. W „Polityce” na szczególną uwagę zasługuje tekst Zdzisława Raczyńskiego Szahid Dżohar ${ }^{44}$, w którym już samo użycie słowa szahid jednoznacznie określa Dudajewa jako człowieka dającego świadectwo swojej wiary, męczennika. Oprócz informacji na temat okoliczności śmierci Dudajewa autor stara się nakreślić możliwe drogi rozwiązania kryzysu. Jak zaznacza Raczyński, „Śmierć Dudajewa jest na rękę przede wszystkim tym siłom w Rosji, które rozpętały krwawą wojnę w Czeczenii, utopiły w niej i rosyjskie społeczeństwo, i prezydenta Jelcyna" ${ }^{45}$. Autor podkreśla też, że sama śmierć Dudajewa nie zakończy krwawych działań w Czeczenii, wręcz przyczyni się do dalszych walk partyzanckich. Zauważa ponadto, że „Dudajew jako zawodowy wojskowy zrozumiał, że Czeczenia nie może wygrać wojny. Jako Czeczeniec - nie mógł skapitulować" 46 .

Sam artykuł kończy dosyć pesymistyczne podsumowanie, w którym autor wyraża przekonanie, że proces stabilizacji sytuacji na Kaukazie będzie niezwykle długotrwały: „Historia XIX w. niewiele nauczyła polityków w Moskwie i bojowników o niepodległą Iczkerię. Teraz, kiedy na sztandarach Czeczenów pojawiło się nowe imię - Szahida Dżohara, historia w ogóle może zostać zapomniana” ${ }^{47}$ W tygodniku „Wprost” ukazał się natomiast artykuł Śmierć legendy autorstwa Jarosława Gizińskiego ${ }^{48}$. Artykuł tak naprawdę stanowi pretekst do rozważań nad przyszłością samej Czeczenii, jak i możliwościami rozwiązania

\footnotetext{
${ }^{40}$ Ibidem.

${ }^{41}$ Ibidem.

${ }^{42}$ Ibidem.

${ }^{43}$ Ibidem.

${ }^{44}$ Z. Raczyński, Szahid Dżohar, „Polityka” 1996, nr 18(2035), s. 38.

${ }^{45}$ Ibidem.

${ }^{46}$ Ibidem.

${ }^{47}$ Ibidem.

${ }^{48}$ J. Giziński, Śmierć legendy, „Wprost” 1996, nr 21, s. 70.
} 
trwającego konfliktu. W opinii autora śmierć Dudajewa wcale nie musi oznaczać ostatecznego zwycięstwa Rosjan nad zbuntowaną republiką, podkreśla także, że konflikt ten był jedną z poważniejszych przeszkód w kampanii prezydenckiej Borysa Jelcyna. Giziński zaznacza również, że

w dającej się przewidzieć przyszłości nic już jednak nie przywróci Czeczenom marzeń o niepodległości. Rejon Kaukazu nieuchronnie wraca pod kontrolę Rosji (...) obok głodującej Armenii, zrujnowanej Gruzji i jeszcze niedawno śniącego o naftowej potędze Azerbejdżanu martwy spokój zapanuje także wśród ruin Groznego ${ }^{49}$.

\section{Podsumowanie}

Przedstawione powyżej grupy tematyczne artykułów poświęconych Czeczenii stanowią najbardziej całościowe ujęcie omawianego zagadnienia na łamach poddanych analizie tygodników opinii. Warto dodać, że oprócz wspomnianych tematów, które były zdecydowanie najpopularniejsze pojawiały się takie zagadnienia, które w sposób dość luźny nawiązywały do kwestii czeczeńskiej. Doskonałym przykładem jest artykuł Zdzisława Raczyńskiego na łamach „Polityki” z 17 grudnia 1994 r. zatytułowany Świat wedtug Kremla ${ }^{50}$, w którym autor nawiązując do wydarzeń na Kaukazie analizuje założenia polityki zagranicznej Federacji Rosyjskiej. Sama wojna czeczeńska stanowiła również pretekst do pogłębionej analizy na łamach prasy sytuacji geopolitycznej na Kaukazie. Wreszcie niektóre teksty szukają odpowiedzi na pytanie o postawę Polski i Polaków wobec tego konfliktu, jak chociażby artykuł Kaukaz pod Tatrami ${ }^{51}$ autorstwa Witolda Beresia z tygodnika „Polityka”, w którym autor rozważał temat pomocy dla Czeczenii a polskiej racji stanu. Warto podkreślić, że wspólną cechą dla wszystkich artykułów w omawianych tygodnikach jest zdecydowane wskazanie dobrej i złej strony w konflikcie, co wyraża się chociażby w warstwie językowej na poziomie samych tytułów. Należy zauważyć, że artykuły zamieszczone w „Polityce” są bardziej wyważone, natomiast te opublikowane na łamach „Wprost” o wiele częściej cechuje emocjonalne podejście do omawianego zagadnienia. Również w ujęciu ilościowym, jak wskazano wcześniej, udział artykułów poświęconych Czeczenii jest bardzo podobny. 